\title{
İmalat İşletmelerinde Enerji Verimliliğinin Yapısal Eșitlik Modeli İle İncelenmesi *
}

\section{Investigation of Energy Efficiency in Manufacturing Enterprises through Structural Equation Model}

\author{
Leyla Şenol a,**, Gülşen Akman ${ }^{\mathrm{b}}$ \\ ${ }^{a}$ Dr., Kocaeli Üniversitesi, Ali Rıza Veziroğlu MYO, Kocaeli/Türkiye \\ ORCID: 0000-0002-5780-9690

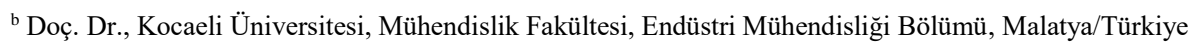 \\ ORCID: 0000-0002-5696-2423
}

\section{MAKALE BILGIISI}

\section{Makale Geçmişi:}

Başvuru tarihi: 10 Mayıs 2018

Düzeltme tarihi: 16 Ekim 2018

Kabul tarihi: 01 Kasım 2018

\section{Anahtar Kelimeler:}

Enerji

Verimlilik

Yönetim

Tasarruf

İşletme

\section{ART ICLE INFO}

\section{Article history:}

Received 10May 2018

Received in revised form 16 October 2018

Accepted 01 November 2018

\section{Keywords:}

Energy

Efficiency

Management

Saving

Enterprise
ÖZ

Bu çalışmanın amacı, enerjinin verimli kullanılması ve tasarrufun sağlanması konusunda katkı sağlamak ve farkındalık yaratmaktır. Bu amaçla imalat işletmelerinden enerji verimliğini etkileyen etmenlerin etki derecelerini ve aralarında ilişki olup olmadığının belirlenmesi için anket yönetimi ile veri toplanmıştır. Faktör analizi sonucunda beş faktör belirlenmiştir. Yapısal Eşitlik modeli analizine göre, otomasyon ve enerji verimliliği arasında istatistiksel olarak anlamlı bir ilişki bulunmamıştır. Ancak, enerji verimliliği ile eğitim, denetim ve yönetim arasında pozitif yönde ve istatistiksel olarak anlamlı bir ilişki olduğu belirlenmiștir. Enerjinin verimli kullanılması ve tasarrufun sağlanması için, çalışanlara eğitim verilmesi, denetimin yapılması ve yönetim faktörünün önemi ortaya konmuştur. Bu bağlamda Enerji verimliliği bilinci her düzeyde geliştirilmeli, var olan enerji politikalarına ilave enerji tasarrufu politikaları oluşturulmalı ve denetim mekanizması ile kontrol sağlanmalıdır.

\section{A B S T R AC T}

The purpose of this study is to contribute to the subject of using energy efficiently and economizing energy consumption as well as to raise awareness about this issue. With this object in mind, data has been gathered from manufacturing businesses through survey management in order to determine the degree of influence of the factors that affect energy efficiency and to make sure whether there is a relationship between them. As a result of the factor analysis, five factors have been detected. According to the Structural Equation Modelling, there has not been found a statistically meaningful relationship between automatization and energy efficiency. However, it has been understood that there is a positive and statistically meaningful relationship between energy efficiency and education as well as between supervision and management. The importance of educating the employees, conducting an inspection and the factor of management has been emphasized so as to use energy efficiency and economize energy consumption. In this respect, awareness for energy efficiency must be improved in all levels, in addition to the existing energy policies energy saving policies must be formed, and control must be provided through inspection mechanism.

\section{Giriş}

Dünyada, her geçen gün artan ekonomik çabalar ve endüstriyel gelişmelerin yanı sıra artan nüfus ve kentleşme ile birlikte enerjiye olan ihtiyaç da artmaktadır. Özellikle sanayi alanında ve günlük yaşamda (yeni teknolojilerin gelişmesi ile) vazgeçilemez bir unsur olan enerji, ülkelerin ekonomik gelişmesinde önemli bir rol oynamaktadır. Enerjiye duyulan ihtiyaç her geçen gün artmaktadır ancak, enerji kaynakları aynı oranda arttırılamamaktadır. Bu durum enerji açığı gibi önemli bir sorunu gündeme getirmektedir.

* Bu çalışma, 2016 yılında Kocaeli Üniversitesi Fen Bilimleri Enstitüsü tarafindan kabul edilen "Yapısal Eşitlik Modelinin Imalat Işletmelerinde Enerji Verimliliğinin Incelenmesi Amacıyla Kullanılması" adlı Doktora tezinden türetilmiştir.

** Sorumlu yazar/Corresponding author.

e-posta: senolleyla4@gmail.com 
$\mathrm{Bu}$ bağlamda ülkelerin giderek artan enerji ihtiyacı dışa bağımlılığın oluşmasına neden olmaktadır. Ülkemiz gibi gelişmekte olan ülkelerde, mevcut sınırlı enerji kaynaklarının etkin ve verimli kullanılmasının, dışa bağımlılı̆̆ı azaltması, enerji darboğazının aşılması ve döviz kaybının önlenmesi açısından son derece önemlidir. $\mathrm{Bu}$ bağlamda enerji verimliliği çözülmesi gereken önemli bir sorundur. $\mathrm{Bu}$ nedenle, enerji üretiminde bir yandan enerji maliyetinin düșürülmesi ve enerji kaynağının arttırılması yönündeki çalışmalar sürdürülürken, bir yandan da aynı enerji miktarıyla daha fazla iş yapılması konusunda tedbirler geliştirilmesi zorunluluktur.

Ülkemizde henüz yeterince değerlendirilmemiş yüksek bir enerji verimliliği potansiyeli bulunmaktadır ve bu potansiyelin değerlendirilmesi çok önemlidir. Ayrıca, enerji yoğunluğunu azaltma, enerji verimliliği konusundaki çalışmaların artması ve kamuoyunda farkındalık yaratılarak, topyekûn enerji verimliliği çalışmalarının başlatılması ve sürdürülmesi bir hükümet politikasıdır. Enerji yoğunluğunun azalmasının, ekonomik büyüme üzerinde önemli bir etkisi bulunmaktadır (Esen ve Aydın, 2018). Enerji Yoğun Bir Tesiste Enerji Verimliliği Proje Tasarımı ve Uygulama konulu çalışmada Özkök (2010), Yüksek miktarda enerji kullanılan bir tesiste kalite ve performansı düşürmeden enerji kullanımını azaltmak için projelerin tasarlanmasına ve uygulanmasına yer verilmiştir. Üretim alanında enerjinin verimli kullanımıyla sağlanacak olan maliyet düşüşünün önemi büyüktür. Sanayide çeşitli alanlarda enerjinin temel bir girdi olduğu göz önünde bulundurulduğunda, enerjinin verimliliği konusunda araştırma yapmanın sağlayacağı katkının da büyüklüğü ortaya çıkmaktadır. Bayraktar (2004) yaptığı yüksek lisans tez çalışmasında, Yatırım yapmadan da sadece, işletim sisteminin değiştirilmesiyle önemli oranlarda kazançlar sağlanacağı vurgulanmış, yatırım gerektiren enerji tasarrufu yöntemleri için ise gerekli olan çalışmalar için maliyet analizi hesaplanarak gösterilmiştir.

Enerji verimliliği çevre ve ekonomi boyutunda ele alınan Özel'in (2010) yüksek lisans tez çalışmasında, enerji kavramsal olarak açıklanmış, kaynakları, kullanımı, çevresel etkileri, finansal sonuçları açıklanmış ve uygulama ile ilgili sonuçlar gösterilmiştir. Üretim alanında enerjinin verimli kullanımıyla sağlanacak olan maliyet düşüşünün önemi büyüktür. Sanayide çeșitli alanlarda enerjinin temel bir girdi olduğu göz önünde bulundurulduğunda, enerjinin verimliliği konusunda araştırma yapmanın sağlayacağı katkının da büyüklüğü ortaya çıkmaktadır.

Ülkemizde sanayi alanında elektrik enerjisinin hangi oranlarda kullanıldı $\breve{1}$, otomotiv sanayinin durumu, otomotiv sektöründe ürün prosesleri, örnek tesisteki enerji verimliliği, enerji tüketim oranları ve ürün başına enerji maliyetine yer verilerek otomotiv sektöründe 1sı enerjisinde yapılabilecek tasarruflar örnek bir tesis üzerinden gösterilmiştir (Uylukçuoğlu, 2009). Enerjinin yoğun kullanıldığı sektör olan imalat sektöründe, kalite standartları göz ardı edilmeden verimliliğin arttırılmasına yönelik enerjinin daha verimli kullanılması kaçınılmazdır. Acar (2012) çalışmasında, enerjinin yoğun olarak kullanıldığı bir fabrikada kalite standartlarına uyarak ve çalışma verimliliğini düşürmeden enerjinin daha etkin kullanılması için, projelerin üretilmesi, yöntemlerin tasarlanması ve maliyet analizlerinin belirlenerek nasıl uygulanacağı gösterilmiştir. Enerji tasarrufu ve enerji verimliliğinin önemi üzerinde durulan
Gökmen'in (2010) tez çalışmasında, aydınlatmayla ilgili enerji tasarrufunun yapacağı katkılar belirtilmiştir. Enerjinin öneminin vurgulandığ 1 gida sektöründe enerji verimliliğine yönelik olarak termodinamik kanunun verimliliği incelenen Taner (2013)'in çalışmasında, örnek olarak ele alınan şeker fabrikasında enerji verimliliği ve enerji yönetimi konusunda çalışılmış ve termodinamik analiz sonuçlarına göre fabrikanın karının arttırılabileceği sonucuna varılmıştır. Çay işletmelerinde kullanılan enerjinin daha verimli kullanılmasının sağlanması yönünde yapılan Korkmaz'ın (2012) çalışmasında, işletmenin enerji tasarrufu için daha çok kaynak ayırması teşvik edilmektedir. Demirtaş'ın (2002) sanayide enerji verimliliği ve uygulaması konulu çalışmasında, ısıtma sisteminde enerji tasarrufunun, bina ve kazan tesisatının değerlendirilmesi yönünde, borulara yapılacak olan izolasyon ile tesisattaki kayıpların en aza indirilebileceği gösterilmiştir.

Sınırlı enerji kaynaklarına sahip ve ihtiyacının önemli bir bölümünü ithal enerji kaynaklarıyla karşılamak zorunda kalan ülkelerin enerjiyi verimli kullanmak ve tasarruf yapma zorunluluğu bulunmaktadır. $\mathrm{Bu}$ nedenle imalat sektöründe enerji verimliliğinin incelenmesi araştırılmaya değer bir konudur. Bu çalışmada, imalat işletmelerinde enerji verimliliği ve tasarrufunu etkileyen faktörlerin belirlenmesi amaçlanmıştır.

Araştırmada, kullanılacak olan model Yapısal Eşitlik Modelidir. Araştırma bir açıklayıcı araştırma türüdür. Açıklayıcı araştırma, genel olarak üzerinde çalışılan değişkenlerin konumunu ve bir değişkenin diğer değişken veya değişkenler üzerindeki etkisini açıklar. Araştırma sonucunda elde edilen veriler, SPSS ve LISREL paket programları ile analiz edilmiştir. Verilerin analizinde öncelikle AFA (Açıklayıcı Faktör Analizi) ve DFA (Doğrulayıcı Faktör Analizi) sonuçları kullanılarak parametrelerin uygunluğu belirlenerek modelin uygunluğunun testi yapılmıştır. Çalışmanın temel değişkenleri için açıklayıcı faktör analizi yapılmış, analiz sonucunda, enerji verimliliğini etkileyen temel faktörler belirlenmiş ve daha sonra her bir temel faktör altındaki alt faktörlerin güvenilirlik analizi yapılmıştır. Çalışma imalat işletmelerinde enerjinin verimli kullanılması ve tasarrufun sağlanması yönünde katkı sağlayacaktır.

\section{Araştırmanın Değişkenleri}

\subsection{Otomasyon}

Kaliteli ve sürekli enerji sağlanabilmesi için sınırlı enerji kaynaklarının verimli kullanmak için enerji iletim sistemlerinin daima izlenmesi ve denetlenmesi bir gerekliliktir. $\mathrm{Bu}$ nedenle enerji iletim ve dağıtım sistemlerinin verileri, doğru ve zamanında elde edilmesi, bu bilgiler doğrultusunda etkili bir şekilde denetimin yapılması tüm dünyada hedeflenmektedir. Ülkemizde özelleştirilen elektrik dağıtım sistemlerinin, Enerji Piyasası Denetleme Kurulu (EPDK) tarafindan denetlenmesi ile konuya verilen önemi göstermektedir. Enerjinin üreticiden tüketiciye kadar olan tüm aşamalarda kontrol altında tutulabilmesi için Denetimli Kontrol ve Veri Toplama (SCADA) sistemlerinin kurulmas1, Enerji İletim Sisteminde uygulanan SCADA sistemleri, üretimde süreç otomasyon sistemlerinin uygulamalarının aksine geniş bir alanı kapsamaktadır. Bir iletişim ağı kullanan otomasyon sistemlerinde tüm cihazlar 
arasında, belirli kurallara bağlı uluşturulan ortak bir lisan olması gerekliliktir. SCADA, otomasyon işlemlerine uygun donatılmış alt yapısıyla enerji iletim ve şebekeleri de karşımıza "Akıllı Şebekeler” olarak çıkmaktadır. Dünyada hedeflenen yeni nesil akıllı enerji şebekeleri için kullanılan teknikler sürekli geliştirilmektedir. Bunun nedeni ise; çeşitli enerji kaynaklarından elde edilen enerjinin daha verimli bir şekilde şebekeye entegre edilmesi, kaliteli ve sürekli enerji sağlanması, sınırlı kaynakların verimli kullanılması, iletimde ve dağıtımda meydana gelebilecek kayıpların en aza indirilmesi, kaçak ve uygunsuz kullanımının engellenmesi ve sonuç olarak enerji verimliliğinin arttırılmasıdır (Otomasyon, 2015).

\subsection{Eğitim}

İşletmelerde üst yönetimler tarafından çalışanlarına periyodik olarak vereceği eğitimlerle ve gerekli durumlarda konunun uzmanlarından alacakları destekle önemli bir ölçüde enerji tasarrufu sağlamaları söz konusudur. Konunun önemi nedeniyle izlenecek yolun belirlenmesi teşvikler, yaptırımlar ve sorumlulukların belirlendiği çalışmalar yürütülmesi ve bu bağlamda da ana tema insan olduğuna göre eğitimin ve bilgilendirmenin önemi ortaya çıkmaktadır. Enerjinin yoğun bir şekilde kullanıldığı sektör olan sanayide sağlanacak olan enerji tasarrufunun sağlayacağı kazançlar büyük olacaktır. Atılacak olan küçük adımlar bilinçlendirme ve eğitim yoluyla sanayide firsatların yakalanmasını sağlayacaktır.

\subsection{Yönetim}

Enerjinin verimli kullanılabilmesi, çalışmaların başlatılabilmesi ve uygulanabilmesi için, İşletme yönetimi tarafından enerji yönetim birimi kurulmalıdır. Her tür işletmede üst yönetimin kararlı tutum ve politikaları ile çalışanların da katılacağı topyekün bir çalışma yapılması kaçınılmazdır. Bu kapsamda işletmelerde enerjinin verimli kullanılmasındaki etkinlik, kararlı ve bilinçli politikalar üreten bir enerji yönetim birimi tarafından gerçekleştirilebilir. Bununla birlikte işletmelerin yalnızca kendilerinin uyguladıkları uygulamalar enerji verimliliği için yeterli değildir. Ülke bazında güçlü bir rekabet için, enerji verimliliği ile ilgili çalışmaların yürütülmesi gerekmektedir. Mevcut olan bilgi ve teknolojinin bilinçsiz kullanımı fırsatların kaçmasına neden olacaktır.

\subsection{Denetim}

İşletmelerde denetim yoluyla, daha etkin ve daha verimli çalışılması, işletmenin varlığının korunarak, devamlılığının sağlanması mümkündür. Üst yönetime sunulan yazılı ve sözlü raporlarda sunulan veriler izlenip değerlendirilerek süreklilik sağlanmalıdır.

Denetimin sonunda karşılaştırma yapılabilmesi için, hedef değerler önceden belirlenmelidir. Belirli aralıklarla raporlama yapılarak hedef değerler ile karşılaştırılmalı ve varsa sapmalar kontrol edilerek yeniden düzenlemeler yapilmalidir.

\subsection{Verimlilik}

Verimlilik kısaca, üretimde kullanılan hammaddenin malzemeye oranidir. Ayrica performansin somut bir göstergesi olarak da tanımlanabilir (Artar, 1992: 505).
Literatürde geçen verimlilik formülü Eşitlik (1)'de gösterilmektedir:

$$
\text { Verimlilik }=\frac{\text { Etkililik }}{\text { Etkenlik }}
$$

Yani amaçlara ne derece ulaşıldığının (etkililik), kaynakların ne derece etken (etkenlik) kullanıldığına oranıdır.

\section{Teorik Modelin ve Hipotezlerin Oluşturulması}

Çalışmanın temel hipotezi: İmalat işletmelerinde enerji verimliliği ile yönetim, denetim, eğitim otomasyon değişkenlerinin birbirleriyle anlamlı ilişkisi vardır.

Çalışmanın temel hipotezini sınamak ve araştırmanın değişkenlerini etkileyen faktörlerin belirlenmesi için YEM oluşturulmuştur.

YEM genel olarak üçe ayrılır. Bunlar; 1. Doğrulayıcı modelleme stratejisi, 2. Alternatif modeller stratejisi, 3. Model Geliştirme Stratejisi (Şimşek, 2007: 3).

Araştırmada bu modelleme stratejileri arasından alternatif modeller stratejisi kullanılmıştır. Çalışmanın hipotezlerinin belirlenmesi için, enerji verimliliği, yönetim, denetim, eğitim ve otomasyon faktörleri incelendi. İnceleme sonucunda model oluşturuldu (Şekil 1).

\subsection{Araştırmanın Teorik Modeli}

Araştırmanın modelindeki değişkenlerden yönetim, denetim, eğitim ve otomasyon dişsal (exogenous) değişkenlerdir. Enerji verimliliği ise içsel (endogenous) değişkendir. Modelde birden çok bağımsız gizil değişken ve bir bağımlı değişken vardır. Birden çok bağımsız değişkenin bağımlı değişken üzerindeki etkisini ölçmek için önerilen model Yapısal Eşitlik Modeli'dir (YEM).

Enerji Verimliliğini Etkileyen Bağımsız Faktörler:

1. Enerji verimliliği faktörü (EVV);2. Denetim faktörü (DENN); 3. Otomasyon faktörü (OTOO); 4. Eğitim faktörü (EGTT); 5. Yönetim faktörüdür (YONN).

Şekil 1. Araştırma modeli

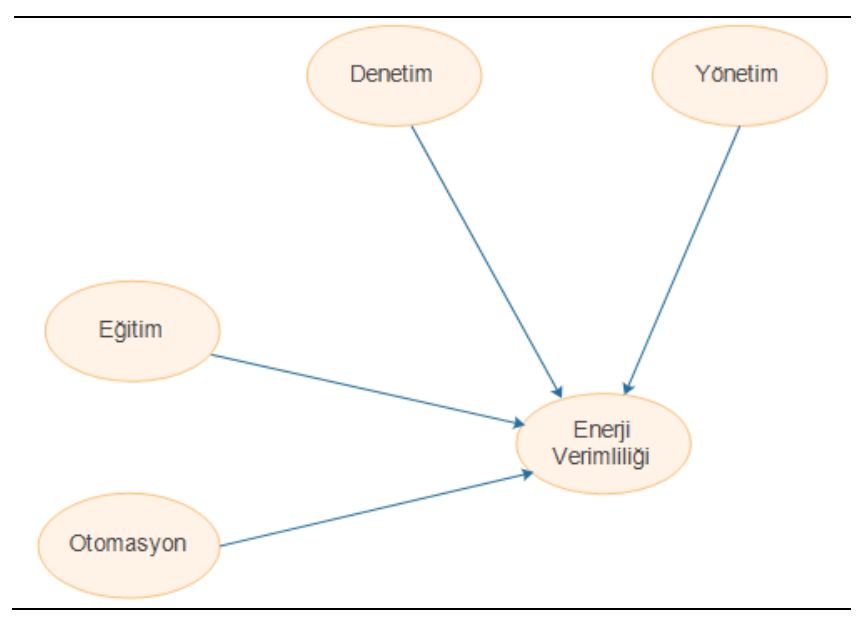

\subsection{Araştırmanın Problem Cümleleri}

Araştırmanın temel problem cümlesi;

- İmalat işletmelerinde enerji verimliliğini etkileyen bağımsız faktörlerden etkin olanları hangileridir? 
Araștırmanın problem cümleleri

- Yönetim ile enerji verimliliği arasında bir ilişki var midır?

- Denetim ile enerji verimliliği arasında bir ilişki var midır?

- Eğitim ile enerji verimliliği arasında bir ilişki var midir?

- Otomasyon ile enerji verimliliği arasında bir ilişki var midir?

- Araştırmanın temel hipotezi "İmalat işletmelerinde enerji verimliliğini etkileyen bağımsız faktörlerle arasında ilişki var mıdır?

\subsection{Araştırma Değişkenleri İle İlgili Hipotezler}

Enerji yoğun kullanılan bir iş yerinde, projeler tasarlanarak uygulanmaya konulması kalite ve performansı düşürmeden enerjinin kullanımını azalttığı ortaya konulmuştur (Özkök, 2010). Bir hizmet sektöründe ise kaynakların kullanımı, çevresel etkileri ve finansal olarak sonuçları açıklanarak, uygulama ile sonuçlar ortaya konulmuştur (Özel, 2010). Yine enerjinin yoğun kullanıldı̆̆ı bir işletmede enerji verimliliği konusunda projelendirilen çalışmaların işletmeler için büyük bütçeler gerektirmediğini ancak kısa vadede bile toplam enerji kullanımında büyük kazançlar elde edildiğini ortaya koyarak yol gösterici olmuştur (Acar, 2012). Bir iş merkezinde enerjinin verimli ve etkin kullanımına yönelik verimlilik arttırıcı proje ile ekonomik ömrü uzun, bakımı kolay ve karlı ürünler önerilmiştir (Adıgüzel, 2011).Bir çay fabrikasında enerji verimliliği analiz edilmiş ve bu araştırma yapılırken hedef, maliyetlerin düşürülmesi, rekabet gücünün arttırılmasına katkı sağlamak olmuştur. Sonuç işletmenin enerji tasarrufu için kaynak ayırması teşvik edilmiştir (Korkmaz, 2012). Sanayide enerji verimliliği ve uygulaması konulu çalışma ile borulara yapılacak olan izolasyon, duvar yalıtımı, 1sı kaybının önlenmesi konusunda önemli ve pozitif bir yönde etkileyeceği gösterilmiştir (Demirtaş, 2002). Enerji verimliliği yatırımlarını etkileyen piyasa odaklı enerji sektörü geliştirmenin, enerji fiyatlarında da anlamlı ve pozitif yönde etkileyeceği vurgulanmıştır (Seabright, Goldstein ve Market, 1996). Enerji duyarlı üretim süreçleri için enerji ve kaynak akışını sağlayan veri modeli ile birlikte zincir tanımlama modeli önerilmiştir (Kreliner, Kunis ve Rünger, 2011). Verimlilik ile enerji verimliliği arasındaki ilişkiyi belirlemek için yapılan çalışmalara dayanılarak şu hipotez geliştirilmiştir:

H1 Verimlilik, enerji verimliliğini önemli ve pozitif bir şekilde etkilemektedir.

TSEN 16001 enerji yönetim sistemi, enerjinin veriminin arttırılmasına yönelik sürekli iyileştirme süreci açısından yararlı ve verimliliğinin de gözlemlenebildiği vurgulanmış ve ilgili enerji yönetim sisteminin enerji verimliliği üzerinde anlamlı ve olumlu katkı yaptığı gösterilmiştir (Erarslan, 2011).

Lastik sektöründe mevcut enerji tüketimi ortaya konarak, iş süreçlerindeki atık ısının geri kazanılması ile iyileştirme önerisi ekonomik olarak değerlendirilerek yüzde on beş enerji tasarrufu sağlandığı, yüzde yirmi de tasarruf olanağı olduğu belirlenmiştir (Sürekli, 1999). Bir şeker fabrikasında ise enerji verimliliği ve enerji yönetimi konusunda çalışılmıştır. İş süreçlerinde iyileştirme yapılabilmesi için değişik senaryo analizleri yapılmış ve fabrikanın karının anlamlı ve olumlu bir şekilde etkileneceği sonucuna varılmıştır (Taner, 2013). Yerel bir işletmede enerji tüketiminin nasıl azaltılacağı gösterilerek, enerji verimliliği yönetimi ile enerji kullanımının azaltılacağı ve sürdürülebilir bir enerji tesisatı kurulmasının anlamlı ve pozitif bir etki sağlayacağı gösterilmiştir (Niesing ve Grobler, 2013). Yönetim ile enerji verimliliği arasındaki ilişkiyi belirlemek için yapılan çalışmalara dayanılarak şu hipotez geliştirilmiştir:

H2 Yönetim, enerji verimliliğini önemli ve pozitif bir şekilde etkilemektedir.

Türkiye'deki kobilerde düşük maliyetli enerji verimliliği yönetim sistemi isimli çalışmada enerji verimliliği anketi ve enerji denetimi ile mevcut sistem analiz edilerek sonuçlar değerlendirilmiştir (Polat, 2013). Bir iş merkezinde ise enerjinin etkin kullanımı incelenmiş ve birincil enerjinin trijenerasyon sistemleri ile ülkemizde de karlı bir şekilde kullanılabileceği gösterilmiştir (Yörük, 2011). Yine Metal Eşya Sektöründe faaliyet gösteren bir firmada enerji tasarrufu konusunda enerji verimliliği yasası ve yönetmeliği doğrultusunda proje çalışması yapılmıştır. Elektrik tasarrufu için öneri yapılarak karı anlamlı ve pozitif bir şekilde etkilediği ortaya konulmuştur (Arıkan, 2010). Denetim ile enerji verimliliği arasındaki ilişkiyi belirlemek için yapılan çalışmalara dayanılarak şu hipotez geliştirilmiştir:

H3 Denetim, enerji verimliliğini önemli ve pozitif bir şekilde etkilemektedir.

Sağlık sektöründe enerji verimliliğini sağlamak için yapılan anket sonuçlarına göre hastanelerde ve sağlık merkezlerinde enerji verimliliğini arttırmak için ilgi ve isteğin, enerji verimliliğini sağlamada anlamlı ve pozitif bir yönde etkisi olduğu ancak, enerji verimliliği bilincinin yayılmasında örgüt engellerinin anlamlı ve negatif bir yönde etkiye sahip olduğu gösterilmiştir (Paulo ve Gomes, 2009). Eğitim ile enerji verimliliği arasındaki ilişkiyi belirlemek için yapılan çalışmalara göre şu hipotez geliştirilmiştir:

H4 Eğitim, enerji verimliliğini önemli ve pozitif bir şekilde etkilemektedir.

Endüstri tesislerinde, verimli enerji aydınlatma teknikleri ile enerji tasarrufunun yapacağı anlamlı ve olumlu katkılar gösterilmiştir (Gökmen, 2010). Aydınlatma sistemlerinde enerji verimliliğinin incelenmesi amacıyla yapılan çalışmada, doğru bir aydınlatmanın tasarrufu anlamlı ve pozitif bir şekilde etkilediği ve bazı faktörlerin aydınlatmayla olan ilişkisi otomasyonla simule edilerek elde edilen sonuçlar değerlendirilmiştir ve otomasyonun enerji verimliliğini pozitif yönde etkilediği sonucu elde edilmiştir (Eser, 2013). Otomasyon ile enerji verimliliği arasındaki ilişkiyi belirlemek için yapılan çalışmalara dayanılarak şu hipotez geliştirilmiştir:

H5 Otomasyon, enerji verimliliğini önemli ve pozitif bir şekilde etkilemektedir.

\section{Anket Formundaki Ölçekler}

\subsection{Enerji verimliliği ölçeği}

(i) Saat başına enerji miktarı beklenen düzeydedir.

(ii) Ürün başına elektrik tüketimi beklenen düzeydedir. 
(iii) 3.Yönetim, her dönem için yeni enerji planları yapmaktadır.

(iv) Enerji verimliliğini sağlamak için, broşürler, posterler ve ilanlar yayımlanmaktadır.

(v) Bölümlerdeki benzer makinelerin enerji harcamaları yakın düzeydedir.

(vi) Bölümlerin enerji tüketim miktarı önceden belirlenmiş hedeflenen miktara yakındır.

(vii) Enerji verimliliğinden sağlanan tasarruf ücretlere yansitılmaktadır.

(viii) İleri teknoloji ve denetimlerle daha az enerji kullanarak aynı üretim miktarına erişilmektedir.

(ix) Enerji tasarrufu üretim maliyetlerini düşürmektedir.

(x) Enerji kayıpları en düşük düzeydedir.

\subsection{Denetim ölçeği}

(i) Daha az enerji kullanarak aynı üretim miktarına erişmek için çalışmalar yapılmaktadır.

(ii) Yönetim enerji verimliliğine önem veren bir anlayışa sahiptir.

(iii) Enerji birimi tarafindan kullanılmayan ekipmanlar devre dışı bırakılmaktadır.

(iv) Bölümlerdeki makinelerin ve tezgahların enerji miktarı ile üretim miktarı karşılaştırılmaktadır.

(v) Enerji tüketen ekipmanların her birine enerji ölçüm cihazları yerleştirilmektedir.

(vi) Fabrikanın bölümlerinde aylık enerji miktarları önemli noktalardaki panolarda grafikle gösterilmektedir.

(vii) Makinelerde hız kontrol cihazları kullanılmaktadır.

\subsection{Otomasyon ölçeği}

(i) Gerekli olmadığında aydınlatma ve havalandırma otomatik olarak kapanmaktadır.

(ii) Fanların hızı otomatik olarak arttırılıp azaltılabilir.

(iii) Makine motorları düşük yükte ve aşırı yükte otomatik olarak durmaktadır.

(iv) Bina girişlerinin aydınlatılması otomatiktir.

(v) Koridor, antre ve depoların havalandırması otomatiktir.

\subsection{Eğitim ölçeği}

(i) Çalışanlara enerji verimliliğini sağlamak için nelere dikkat etmeleri gerektiği eğitim çalışmalarında açıklanmaktadır.

(ii) Enerji verimliliğinin maliyetleri düşüreceği, bunun çalışanların ücretlerine yansıyacağı eğitim çalışmalarında anlatılmaktadır.

(iii) Çalışanlara belirli aralıklarla enerji verimliliği eğitimi verilmektedir.

4.5. Yönetim ölçeği

(i) Yönetim enerji verimliliği ile ilgili önerilere her zaman açıtır.

(ii) 2. Yönetim enerji ve malzeme tüketimini azaltmak için çalışmalar yapmaktadır.

(iii) 3. Enerji verimliliği politikalarını işyerindeki tüm çalışanlar bilmektedir.

(iv) 4. Yönetim benzer fabrikalardaki enerji tüketim miktarları ile kendi enerji tüketim miktarını karşılaştırmaktadır.

\section{Araştırmanın Teknikleri}

$\mathrm{Bu}$ çalışma açıklayıcı araştırma türüdür. Açıklayıcı araştırma, konuya esas olan değişkenlerin konumunu, bir değişkenin diğer değişkenler üzerindeki etkisini açıklar. Araştırma sonucunda elde edilen veriler, SPSS ve LISREL paket programları kullanılarak değerlendirilmiştir. Değerlendirmede önce AFA (Açıklayıcı Faktör Analizi) ve DFA (Doğrulayıcı Faktör Analizi) kullanılarak faktörlerin uygunluğu ve sonrasında modelin uygunluğu test edildi. Araştırmanın modelinde birden çok bağımsız gizil değişken ve bağımlı değişken bulunmaktadır. Birden çok bağımsız ve birden çok bağımlı değişken arasındaki birden fazla (çoklu) ilişkiler için önerilen model Yapısal Eşitlik modelidir. Veriler, Kocaeli bölgesindeki imalat sektöründe çalışanlara anket uygulanarak, tanımlayıcı istatistik teknikleri ve Açıklayıcı Faktör Analizi SPSS paket programı ve DFA ve YEM, LInear Structural RELations (LISREL) paket programı ile test edildi.

\subsection{Ana Kitle ve Örnek Kitle}

Araştırmada ana problem, imalat işletmelerinde enerji verimliliğini etkileyen bağımsız faktörlerden etkin olanlarının belirlenmesidir. Araştırma probleminin çözümünde, Kocaeli Bölgesindeki imalat işletmeleri kullanıldı. Örnek kitle iş yerinde çalışan işçileri kapsamakta olup yöneticiler ve denetçileri kapsamamaktadır.

\subsection{Veri Toplama Arac1}

İmalat işletmelerinde uygulanacak anket formu beş bölümden oluşmaktadır. Öncelikle araştırmanın problemini çözebilmek için veriler literatür araştırmasıyla belirlendi. Daha sonra konuyla ilgili sorular sınıflandırılmış olup, örnek kütleden belirli sayıda yanıtlayıcılarla görüşüldü.

\section{Verilerin Analizi}

\subsection{Açıklayıcı Faktör Analizi}

Enerji verimliliğini belirlemede etkili olan faktörleri ortaya çıkarmak için, açıklayıcı faktör analizi yapıldı. Analizde temel bileşenler analizi tekniği kullanıldı. Faktörlerin kendilerine yüksek destek sağlayan maddeleri bulması için, en yaygın olarak kullanılan döndürme yöntemlerinden maksimum değişkenlik (varimax) yöntemi kullanıldı.

Araştırma konusu ile ilgili çalışmalarda kullanılan ölçeklerden yararlanarak 29 sorudan oluşturulan soru formu 5 farklı fabrikadaki işçilere soruldu ve faktörler onların verdiği yanıtlara göre belirlendi. 
Tablo 1. Araştırma Değişkenlerinin Ortalamaları ve Standart Sapmaları

\begin{tabular}{|c|c|c|}
\hline Maddeler & Ortalamalar & Std. Sapma. \\
\hline 1. OTOO1. Gerekli olmadığında aydınlatma ve havalandırma otomatik olarak kapanmaktadır. & 4,67 & 0,627 \\
\hline 2. OTOO2. Koridor, antre ve depoların havalandırması otomatiktir. & 4,58 & 0,653 \\
\hline 3. OTOO3. Fanların hızı otomatik olarak arttırılıp azaltılmaktadır. & 4,52 & 0,662 \\
\hline 4. OTOO4. Makine motorları düşük yükte ve aşırı yükte otomatik olarak durmaktadır. & 4,64 & 0,663 \\
\hline 5. OTOO5. Binaların giriş aydınlatması otomatiktir. & 4,46 & 0,689 \\
\hline $\begin{array}{l}\text { 6. EGTT1. Çalışanlara enerji verimliliğini sağlamak için nelere dikkat etmeleri gerektiği eğitim } \\
\text { çalışmalarında açıklanmaktadır. }\end{array}$ & 4,47 & 0,776 \\
\hline $\begin{array}{l}\text { 7. EGTT2. Enerji verimliliğinin maliyetleri düşüreceği, bunun çalışanların ücretlerine yansıyacağı eğitim } \\
\text { çalışmalarında anlatılmaktadır. }\end{array}$ & 4,61 & 0,620 \\
\hline 8. EGTT5. Çalışanlara belirli aralıklarla enerji verimliliği eğitimi verilmektedir. & 4,51 & 0,672 \\
\hline 9. EVV1. İleri teknoloji ve denetimlerle daha az enerji kullanarak aynı üretim miktarına erişilmektedir. & 4,47 & 0,653 \\
\hline 10. EVV2. Bölümlerin enerji tüketim miktarı önceden belirlenmiş hedeflenen miktara yakındır. & 4,44 & 0,627 \\
\hline 11. EVV3. Saat başına enerji miktarı beklenen düzeydedir. & 4,38 & 0,676 \\
\hline 12. EVV4. Ürün başına elektrik tüketimi beklenen düzeydedir. & 4,35 & 0,714 \\
\hline 13. EVV5. Enerji verimliliğinden sağlanan tasarruf ücretlere yansitılmaktadır. & 4,13 & 0,990 \\
\hline 14. EVV6. Bölümlerdeki benzer makinelerin enerji harcamaları yakın düzeydedir. & 4,33 & 0,761 \\
\hline 15. EVV7. Enerji tasarrufu üretim maliyetlerini düşürmektedir. & 4,52 & 0,698 \\
\hline 16. EVV8. Enerji kayıpları en düşük düzeydedir. & 4,15 & 0,876 \\
\hline 17. EVV9. Yönetim her dönem için yeni enerji planları yapmaktadır. & 4,41 & 0,665 \\
\hline 18. EVV10. Enerji verimliliğini sağlamak için, broşürler, posterler ve ilanlar yayımlanmaktadır. & 4,36 & 0,728 \\
\hline 19. DENN1. Enerji tüketen ekipmanların her birine enerji ölçüm cihazları yerleştirilmektedir. & 0,452 & 0,662 \\
\hline 20. DENN2. Daha az enerji kullanmak aynı üretim miktarına erişmek için çalışmalar yapılmaktadır. & 4,54 & 0,657 \\
\hline 21. DENN3. Enerji birimi tarafından kullanılmayan ekipmanlar devre dışı bırakılmaktadır. & 4,53 & 0,662 \\
\hline 22. DENN4. Bölümlerdeki makinelerin ve tezgahların enerji miktarı ile üretim miktarı karşılaştırılmaktadır. & 4,56 & 0,669 \\
\hline $\begin{array}{l}\text { 23. DENN5. Fabrikanın bölümlerinde aylık enerji miktarları önemli noktalardaki panolarda grafikle } \\
\text { gösterilmektedir. }\end{array}$ & 4,47 & 0,776 \\
\hline 24. DENN6. Makinelerde hız kontrol cihazları bulunmaktadır. & 4,51 & 0,737 \\
\hline 25. DENN7. Yönetim enerji verimliliğine önem veren bir anlayışa sahiptir. & 4,56 & 0,683 \\
\hline 26. YONN1. Yönetim enerji verimliliği ile ilgili önerilere her zaman açıtır. & 4,40 & 0,592 \\
\hline 27. YONN2. Yönetim enerji ve malzeme tüketimini azaltmak için çalışmalar yapmaktadır. & 4,37 & 0,717 \\
\hline 28. YONN3. Enerji verimliliği politikalarını işyerindeki tüm çalışanlar bilmektedir. & 4,70 & 0,616 \\
\hline $\begin{array}{l}\text { 29. YONN4. Yönetim benzer fabrikalardaki enerji tüketim miktarları ile kendi enerji tüketim miktarını } \\
\text { karşılaştırmaktadır. }\end{array}$ & 4,41 & 0,652 \\
\hline
\end{tabular}

Tablo 2. Toplam Açıklanan Varyans

\begin{tabular}{|c|c|c|c|c|c|c|c|c|c|}
\hline \multicolumn{10}{|c|}{ Total Variance Explained } \\
\hline \multirow{2}{*}{ Component } & \multicolumn{2}{|c|}{ Initial Eigenvalues } & \multicolumn{4}{|c|}{ Extraction Sums of Squared Loadings } & \multicolumn{3}{|c|}{ Rotation Sums of Squared Loadings } \\
\hline & Total & $\%$ of Variance & Cumulative $\%$ & Total & $\%$ of Variance & Cumulative $\%$ & Total & $\%$ of Variance & Cumulative $\%$ \\
\hline 1 & 8,506 & 29,330 & 29,330 & 8,506 & 29,330 & 29,330 & 3,589 & 12,377 & 12,377 \\
\hline 2 & 2,351 & 8,105 & 37,436 & 2,351 & 8,105 & 37,436 & 3,080 & 10,622 & 22,998 \\
\hline 3 & 2,011 & 6,936 & 44,371 & 2,011 & 6,936 & 44,371 & 2,563 & 8,839 & 31,837 \\
\hline 4 & 1,459 & 5,031 & 49,402 & 1,459 & 5,031 & 49,402 & 2,139 & 7,376 & 39,213 \\
\hline 5 & 1,362 & 4,696 & 54,098 & 1,362 & 4,696 & 54,098 & 2,111 & 7,279 & 46,492 \\
\hline 6 & 1,261 & 4,349 & 58,447 & 1,261 & 4,349 & 58,447 & 1,940 & 6,689 & 53,181 \\
\hline 7 & 1,086 & 3,746 & 62,193 & 1,086 & 3,746 & 62,193 & 1,874 & 6,463 & 59,644 \\
\hline 8 & 1,035 & 3,569 & 65,762 & 1,035 & 3,569 & 65,762 & 1,774 & 6,118 & 65,762 \\
\hline 9 &, 951 & 3,281 & 69,043 & & & & & & \\
\hline 10 &, 880 & 3,035 & 72,078 & & & & & & \\
\hline 11 &, 787 & 2,715 & 74,793 & & & & & & \\
\hline 12 & ,738 & 2,546 & 77,339 & & & & & & \\
\hline 13 &, 688 & 2,373 & 79,711 & & & & & & \\
\hline 14 &, 649 & 2,237 & 81,949 & & & & & & \\
\hline 15 &, 623 & 2,150 & 84,099 & & & & & & \\
\hline 16 &, 556 & 1,919 & 86,017 & & & & & & \\
\hline 17 &, 528 & 1,822 & 87,840 & & & & & & \\
\hline 18 &, 502 & 1,732 & 89,572 & & & & & & \\
\hline 19 &, 466 & 1,607 & 91,179 & & & & & & \\
\hline 20 &, 441 & 1,521 & 92,700 & & & & & & \\
\hline 21 &, 424 & 1,461 & 94,161 & & & & & & \\
\hline 22 & ,396 & 1,364 & 95,526 & & & & & & \\
\hline 23 &, 337 & 1,161 & 96,686 & & & & & & \\
\hline 24 & ,321 & 1,108 & 97,794 & & & & & & \\
\hline 25 & ,290 & 1,000 & 98,795 & & & & & & \\
\hline 26 & ,251 &, 865 & 99,659 & & & & & & \\
\hline 27 & ,038 & ,131 & 99,791 & & & & & & \\
\hline 28 &, 036 & 125 & 99,916 & & & & & & \\
\hline 29 &, 024 &, 084 & 100,000 & & & & & & \\
\hline
\end{tabular}


Faktör analizi ile birlikte, Kaiser-Meyer-Olkin (KMO) ve Barlett's Küresellik testi de yapıldı. Faktör analizi ile birlikte yapılan KMO testindeki değer 0,840 olduğundan örnek hacmi faktör analizi yapmaya uygun olduğu görüldü. Bununla birlikte Barlett's önem değeri 0,00 olduğundan, değișkenler arasında faktör analizi yapmaya yeterli düzeyde bir ilişki olduğu anlaşıldı.

Anket formundaki her maddenin faktör analizine uygun olup olmadığını görmek için, “Anti-Image Correlation" bölümündeki Measures of Sampling Adequacy (MSA) değeri 0,50 'den düşük soru olmadığından, tüm sorularla analizlere devam edildi (Sipahi, 2010: 79).

Rotated Companent Matrix çizelgesindeki maddelerin yük değerleri için bir kabul noktası belirlenir. Örneğin bu nokta 0,30 olabilir (Sipahi, 2010: 79). Faktör analizinde oluşan "Rotated Companent Matrix"e göre MSA yük değerleri 0,30'dan düşük madde olmadığından, hiçbiri analizden çıkartılmadı. Total Variance Explained çizelgesine göre özdeğerleri "1"den büyük 8 faktör önerilmektedir fakat 5 . Faktörden sonraki değerler giderek düştüğünden, 5 faktör olması uygun bulundu (Tablo 2).

Faktör sayısını 5 olarak kabul edebilmek için, "scree plot" grafiğinin (yamaç birikim grafiği) incelendi. Şekil 2'de 5. noktadan sonra eğim bir plato yapmaktadır. Bu noktadan sonraki faktörlerin varyansa yaptıkları katkı hem küçük hem de yaklaşık olarak aynıdır. Bu nedenle faktör sayısının 5 olmasina karar verildi.

Şekil 2. Yamaç Grafiği

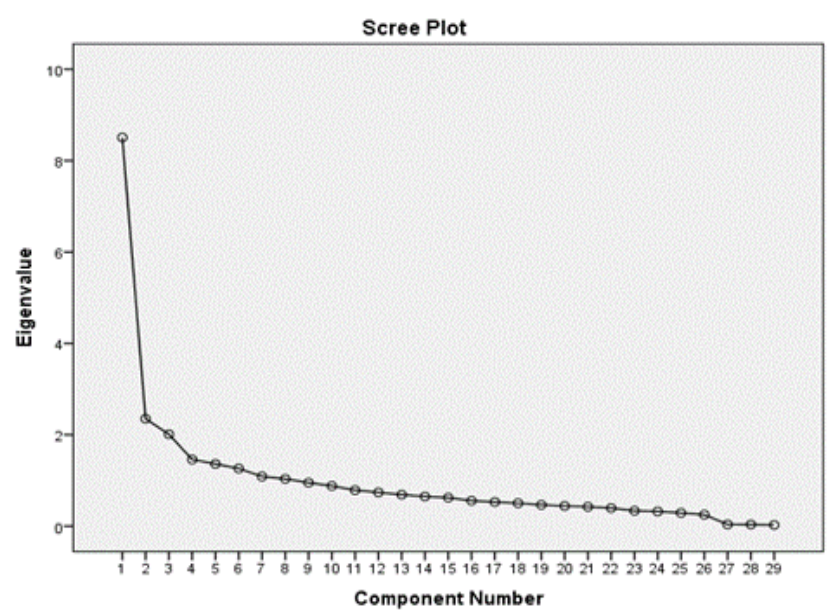

Açıklayıcı faktör analizi bu kez 5 faktöre göre yapıldı ve Total Variance Explained" Tablo 3'e göre özdeğerleri (eigenvalues) "1" den büyük 5 faktör ortaya çıkmıştır (Şekil 2).

Tablo 3. Toplam Açıklanan Varyans

\begin{tabular}{ccccccc}
\hline & \multicolumn{3}{c}{ İlk Özdeğerler } & \multicolumn{3}{c}{$\begin{array}{c}\text { Kareli Yüklerin Rotasyon } \\
\text { Toplamları }\end{array}$} \\
\hline \multirow{2}{*}{ Bileşen } & Top. & $\begin{array}{c}\text { Varyans } \\
\%\end{array}$ & $\begin{array}{c}\text { Birikimli } \\
\%\end{array}$ & Top. & $\begin{array}{c}\text { Varyans } \\
\%\end{array}$ & $\begin{array}{c}\text { Birikimli } \\
\%\end{array}$ \\
\hline 1 & 8,506 & 29,330 & 29,330 & 4,627 & 15,955 & 15,955 \\
2 & 2,351 & 8,105 & 37,436 & 4,434 & 15,288 & 31,243 \\
3 & 2,011 & 6,936 & 44,371 & 2,973 & 10,250 & 41,493 \\
4 & 1,459 & 5,031 & 49,402 & 1,959 & 6,754 & 48,247 \\
5 & 1,362 & 4,696 & 54,098 & 1,697 & 5,850 & 54,098 \\
\hline
\end{tabular}

İkinci faktör analizinden sonra 5 faktörün altındaki maddelerin yük değerleri Tablo 4'te görülmektedir.
Tablo 4. Döndürülmüş Bileşenler Matrisi

\begin{tabular}{|c|c|c|c|c|c|}
\hline Bileşen & 1. Faktör & 2. Faktör & 3. Faktör & 4. Faktör & 5. Faktör \\
\hline 1 & 0,754 & & & & \\
\hline 2 & 0,753 & & & & \\
\hline 3 & 0,741 & & & & \\
\hline 4 & 0,741 & & & & \\
\hline 5 & 0,697 & & & & \\
\hline 6 & 0,587 & & & & \\
\hline 7 & 0,582 & & & & \\
\hline 8 & 0,495 & & & & \\
\hline 9 & 0,468 & & & & \\
\hline 10 & 0,459 & & & & \\
\hline 11 & & 0,759 & & & \\
\hline 12 & & 0,745 & & & \\
\hline 13 & & 0,696 & & & \\
\hline 14 & & 0,692 & & & \\
\hline 15 & & 0,675 & & & \\
\hline 16 & & 0,638 & & & \\
\hline 17 & & 0,625 & & & \\
\hline 18 & & & 0,707 & & \\
\hline 19 & & & 0,670 & & \\
\hline 20 & & & 0,658 & & \\
\hline 21 & & & 0,615 & & \\
\hline 22 & & & 0,603 & & \\
\hline 23 & & & & 0,711 & \\
\hline 24 & & & & 0,679 & \\
\hline 25 & & & & 0,480 & \\
\hline 26 & & & & & 0,559 \\
\hline 27 & & & & & 0,526 \\
\hline 28 & & & & & 0,469 \\
\hline 29 & & & & & 0,390 \\
\hline
\end{tabular}

\subsection{Güvenilirlik Analizi}

Açıklayıcı faktör analiziyle belirlenen faktör yapılarının güvenilirliğini belirlemek için, her bir yapı Alpha modeli kullanılarak güvenilirlik analizine tabi tutuldu. Araştırma değişkenleriyle ilgili güvenilirlik katsayılarının yüksek olması, ölçek yapılarının güvenilir olduğunu göstermektedir (Tablo 5).

Tablo 5. Güvenilirlik Analizi Sonuçları

\begin{tabular}{lc}
\hline Faktörler & Cronbach Alfa \\
\hline 1. Enerji Verimliliği & 0,869 \\
2. Denetim Faktörü & 0,863 \\
3. Otomasyon Faktörü & 0,744 \\
4. Eğitim Faktörü & 0,674 \\
5. Yönetim Faktörü & 0,661 \\
\hline
\end{tabular}

Değişkenlerin Cronbch's Alpha değerinin 0,70 ve üzerinde olması, sorular arasındaki korelasyonun güvenilir olduğunu gösterir. Ancak soru sayısının az olması halinde bu değer 0,60 ve üstü olarak kabul edilebilir (Sipahi, 2010).

Likert ölçeği ile toplanan verilerin faktör analizi sonucunda beş faktör belirlenmiştir. Güvenilirlik analizi yapılan bu faktörler; 1. Enerji verimliliği faktörü (EVV); 2. Denetim faktörü (DENN); 3. Otomasyon faktörü (OTOO); 4. Eğitim faktörü (EGTT); 5. Yönetim faktörüdür (YONN) .

\subsection{Birinci Faktör Enerji Verimliliği Faktörü}

(i) EVV3. Saat başına enerji miktarı beklenen düzeydedir.

(ii) EVV4. Ürün başına elektrik tüketimi beklenen düzeydedir.

(iii) EVV9. Yönetim, her dönem için yeni enerji planları yapmaktadir. 
(iv) EVV10. Enerji verimliliğini sağlamak için, broşürler, posterler ve ilanlar yayımlanmaktadır.

(v) EVV6. Bölümlerdeki benzer makinelerin enerji harcamaları yakın düzeydedir.

(vi) EVV2. Bölümlerin enerji tüketim miktarı önceden belirlenmiş hedeflenen miktara yakındır.

(vii) EVV5. Enerji verimliliğinden sağlanan tasarruf ücretlere yansitilmaktadır.

(viii) EVV1. İleri teknoloji ve denetimlerle daha az enerji kullanarak aynı üretim miktarına erişilmektedir.

(ix) EVV7. Enerji tasarrufu üretim maliyetlerini düşürmektedir.

(x) EVV8. Enerji kayıpları en düşük düzeydedir.

\section{4. İkinci Faktör Denetim Faktörü}

(xi) DENN2. Daha az enerji kullanarak aynı üretim miktarına erişmek için çalışmalar yapılmaktadır.

(xii) DENN7. Yönetim enerji verimliliğine önem veren bir anlayışa sahiptir.

(xiii) DENN3. Enerji birimi tarafından kullanılmayan ekipmanlar devre dışı bırakılmaktadır.

(xiv) DENN4. Bölümlerdeki makinelerin ve tezgahların enerji miktarı ile üretim miktarı karşılaştırılmaktadır.

(xv) DENN1. Enerji tüketen ekipmanların her birine enerji ölçüm cihazları yerleştirilmektedir.

(xvi) DENN5. Fabrikanın bölümlerinde aylık enerji miktarları önemli noktalardaki panolarda grafikle gösterilmektedir.

(xvii) DENN6. Makinelerde hiz kontrol cihazları kullanılmaktadır.

\section{5. Üçüncü Faktör Otomasyon Faktörü}

(xviii) OTOO1. Gerekli olmadığında aydınlatma ve havalandırma otomatik olarak kapanmaktadır.

(xix) OTOO3. Fanların hızı otomatik olarak arttırılıp azaltılabilir.

(xx) OTOO4. Makine motorları düşük yükte ve aşırı yükte otomatik olarak durmaktadır.

(xxi) OTOO5. Bina girişlerinin aydınlatılması otomatiktir.

(xxii) OTOO2. Koridor, antre ve depoların havalandırması otomatiktir.

\subsection{Dördüncü Faktör Eğitim Faktörü}

(xxiii) EGTT1. Çalışanlara enerji verimliliğini sağlamak için nelere dikkat etmeleri gerektiği eğitim çalışmalarında açıklanmaktadır.

(xxiv) EGTT2. Enerji verimliliğinin maliyetleri düşüreceği, bunun çalışanların ücretlerine yansıyacağı eğitim çalışmalarında anlatılmaktadır.

(xxv) EGTT5. Çalışanlara belirli aralıklarla enerji verimliliği eğitimi verilmektedir.

\subsection{Beşinci Faktör Yönetim Faktörü}

(xxvi) YONN1. Yönetim enerji verimliliği ile ilgili önerilere her zaman açıktır.

(xxvii) YONN2. Yönetim enerji ve malzeme tüketimini azaltmak için çalıșmalar yapmaktadır.

(xxviii) YONN3. Enerji verimliliği politikalarını işyerindeki tüm çalışanlar bilmektedir.

(xxix) YONN4. Yönetim benzer fabrikalardaki enerji tüketim miktarları ile kendi enerji tüketim miktarını karşılaştırmaktadır.
Sonuç olarak, enerji verimliliğini etkileyen faktörlerle ilgili sorulara ișçilerin verdiği yanıtlara göre yapılan faktör analizi sonucunda, birbirine benzer sorular birbirlerine yaklaşarak, beş faktör altında toplanmıştır. Bu faktörlerden birincisi enerji verimliliği faktörü; ikincisi denetim faktörü; üçüncüsü otomasyon faktörü; dördüncüsü eğitim faktörü; beşincisi yönetim faktörüdür.

\section{Araştırma Modelinin Analizi}

\subsection{Birinci Aşama: Doğrulayıcı Faktör Analizi}

Doğrulayıcı faktör analizinde hata varyansı 1,96'dan küçük olan maddeler ve çok fazla düzeltme önerisi olan maddeler analizden çıkartılır(Çelik, vd. 2013: 120) Açıklayıcı faktör analizi ile belirlenen ve daha sonra güvenilirlik analizinde kabul edilen 29 madde doğrulayıcı faktör analizine sokuldu.

$\mathrm{Bu}$ maddelerden EVV4'ün hata varyans1 $(1,29<196)$, DENN2'nin hata varyansı $(0,49<1,96)$ olduğundan analizden çıkarıldı. Düzeltme indekslerinde EVV9 maddesi için $6 \mathrm{kez}$, YONN3 maddesi için $5 \mathrm{kez}$, EVV8 maddesi için $6 \mathrm{kez}$, DENN4 maddesi için $5 \mathrm{kez}$, DENN1 maddesi için $5 \mathrm{kez}$, EVV2 maddesi için $4 \mathrm{kez,} \mathrm{EVV7} \mathrm{maddesi} \mathrm{için} 5 \mathrm{kez}$, OTOO5 maddesi için 4 kez düzeltme önerisinde bulunulduğundan, bu maddeler analizden çıkartıldı. DFA analizi sonucunda elde edilen uyum değerlerinden sadece GFI'nin değeribiraz düşüktür, diğerlerinin değerleri uyum indekslerinde verilen aralıklarda olduğundan, yol diyagramı istatistiksel olarak anlamlidir (Tablo 6).

Tablo 6. Doğrulayıcı Faktör Analizinin Uyum Değerleri

\begin{tabular}{|c|c|c|c|}
\hline $\begin{array}{l}\text { Uyumluluk } \\
\text { İndeksi }\end{array}$ & $\begin{array}{c}\text { Modifikasyon } \\
\text { Sonras1 } \\
\text { Değerler }\end{array}$ & İyi Uyum & $\begin{array}{c}\text { Kabul Edilebilir } \\
\text { Uyum }\end{array}$ \\
\hline $\begin{array}{c}\mathrm{Ki}- \\
\text { Kare/SD }\end{array}$ & $\begin{array}{c}451,77 / 138= \\
3,273\end{array}$ & $1-2$ & $3-5$ \\
\hline RMSEA & 0,085 & $0<$ RMSEA $<0,05$ & $0,05<$ RMSEA $<0,10$ \\
\hline NFI & 0,935 & $0,95 \leq \mathrm{NFI} \leq 1,00$ & $0,90 \leq \mathrm{NFI} \leq 0,95$ \\
\hline CFI & 0,954 & $0,95 \leq \mathrm{CFI} \leq 1,00$ & $0,90 \leq \mathrm{CFI} \leq 0,95$ \\
\hline SRMR & 0,0628 & $0,00 \leq \mathrm{SRMR} \leq 0,05$ & $0,05 \leq \mathrm{SRMR} \leq 0,10$ \\
\hline GFI & 0,837 & $0,95 \leq \mathrm{GFI} \leq 1,00$ & $0,90 \leq \mathrm{GFI} \leq 0,95$ \\
\hline
\end{tabular}

Bir modelin ayırt edici özelliğine göre kabul edilebilmesi için, doğrulayıcı faktör analizi sonunda elde edilen korelasyon katsayılarının aşırı yüksek olmaması gerekir (Örneğin <0,85) (Büyüköztürk, 2010) Doğrulayııı faktör analizi sonucunda oluşturulan korelasyon analizinde, araştırma değişkenleri arasındaki korelasyon katsayılarının 0,85'den küçüktür. Sonuç olarak, değişkenler arasındaki ilişkiler çok küçük değildir. "yakınsak geçerliliği" (convergent validity) ve aynı zamanda çok büyük değildir “Ayırt edici geçerliliğii” (discriminant validity) (Tablo 7).

Tablo 7. Araştırma Değişkenleri Arasındaki Korelasyon Değerleri

\begin{tabular}{cccccc}
\hline & OTOO & EGTT & DENN & YONN & EVV \\
\hline OTOO & 1 & & & & \\
EGTT & 0,572 & 1 & & & \\
DENN & 0,585 & 0,493 & 1 & & \\
YONN & 0,451 & 0,693 & 0,658 & 1 & \\
EVV & 0,498 & 0,667 & 0,732 & 0,693 & 1 \\
\hline
\end{tabular}

Analizde her değişken için en az 3 madde belirlenmiştir (Tablo 7). Bu maddelerin standart değerleri, $\mathrm{R}^{2}$ değerleri, hata varyansları, t-değerleri istenen değerlerdedir. Standart değerler çok yüksek değil, hata varyansları aşırı yüksek 
değildir, t- değerleri 0,05 önem düzeyinde 1,96'dan küçük değildir (Tablo 8).

Tablo 8. Doğrulayıcı Faktör Analizi Değerleri

\begin{tabular}{|c|c|c|c|c|}
\hline $\begin{array}{c}\text { Faktörler ve } \\
\text { Maddeler }\end{array}$ & $\begin{array}{c}\text { Standart } \\
\text { Değer }\end{array}$ & $\begin{array}{c}\mathrm{R}^{2} \\
\text { Değerleri }\end{array}$ & $\begin{array}{c}\text { Hata } \\
\text { Varyans1 }\end{array}$ & $\begin{array}{c}\mathrm{T}- \\
\text { Değerleri }\end{array}$ \\
\hline \multicolumn{5}{|l|}{$\begin{array}{l}\text { Otomasyon } \\
\text { (OTOO) }\end{array}$} \\
\hline OTOO3 & 0,61 & 0,370 & 0,63 & 11,68 \\
\hline OTOO4 & 0,88 & 0,766 & 0,23 & 17,91 \\
\hline OTOO1 & 0,77 & 0,592 & 0,41 & 15,06 \\
\hline OTOO2 & 0,44 & 0,190 & 0,81 & 7,58 \\
\hline \multicolumn{5}{|l|}{ Eğitim (EGTT) } \\
\hline EGTT2 & 0,53 & 0,277 & 0,72 & 9,17 \\
\hline EGTT5 & 0,89 & 0,797 & 0,20 & 17,31 \\
\hline EGTT1 & 0,72 & 0,513 & 0,49 & 13,39 \\
\hline \multicolumn{5}{|c|}{$\begin{array}{l}\text { Enerji verimliliği } \\
\text { (EVV) }\end{array}$} \\
\hline EVV10 & 0,70 & 0,492 & 0,51 & 13,46 \\
\hline EVV5 & 0,62 & 0,387 & 0,61 & 11,60 \\
\hline EVV3 & 0,74 & 0,546 & 0,45 & 14,95 \\
\hline EVV6 & 0,73 & 0,538 & 0,46 & 14,32 \\
\hline EVV1 & 0,80 & 0,632 & 0,37 & 16,10 \\
\hline \multicolumn{5}{|c|}{ Denetim (DENN) } \\
\hline DENN3 & 0,88 & 0,773 & 0,23 & 19,14 \\
\hline DENN6 & 0,60 & 0,355 & 0,65 & 11,24 \\
\hline DENN5 & 0,44 & 0,193 & 0,81 & 7,88 \\
\hline DENN7 & 0,92 & 0,848 & 0,15 & 20,59 \\
\hline \multicolumn{5}{|l|}{$\begin{array}{l}\text { Yönetim } \\
\text { (YONN) }\end{array}$} \\
\hline YONN4 & 0,77 & 0,599 & 0,40 & 14,26 \\
\hline YONN2 & 0,60 & 0,362 & 0,64 & 10,59 \\
\hline YONN1 & 0,62 & 0,384 & 0,62 & 11,11 \\
\hline
\end{tabular}

Önem düzeyi $\mathrm{p}<0,05$

Şekil 3. Teorik Modelin t-Değerlerini Gösteren Ölçme Modeli

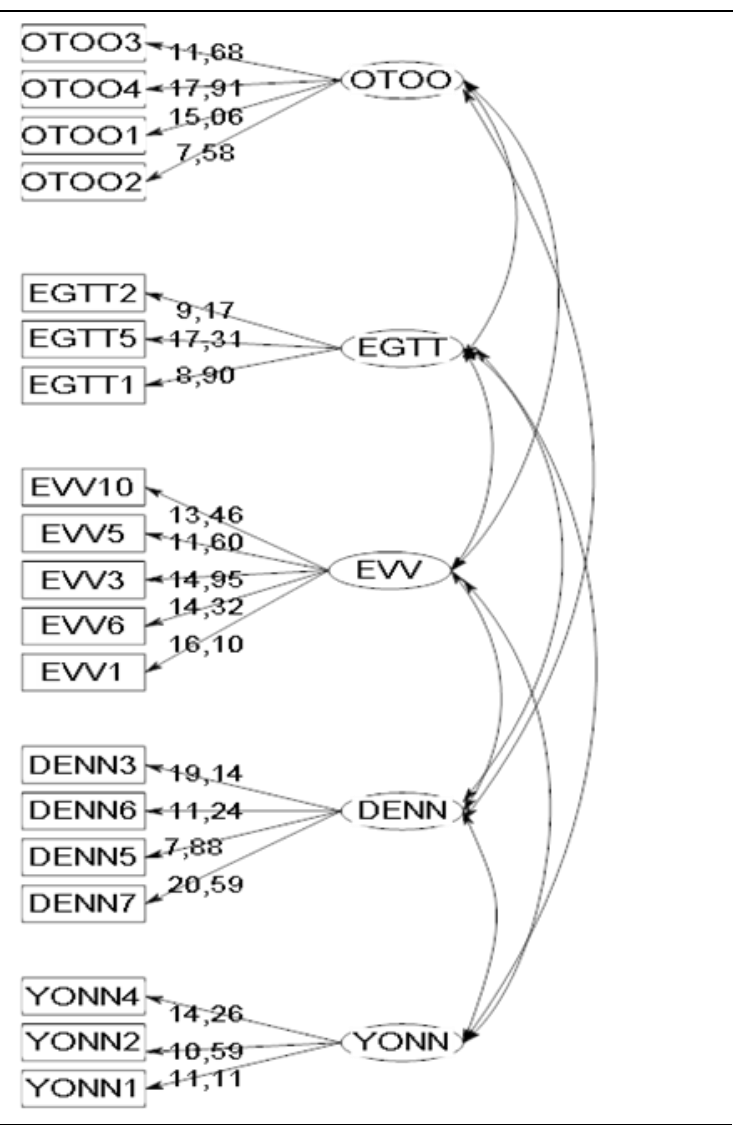

Ölçme modeline ilişkin analiz sonuçlarına göre, bu model yeterli uyum iyiliği değerleri üretmiş olduğundan, kabul edilebilir bir modeldir.

Ki-kare değeri $=451,77 \quad \mathrm{sd}=138 \quad \mathrm{p}$ değeri $=0,000$ RMSEA $=0,085$

7.2. İkinci Aşama: YEM Analizi ve Hipotez Testleri Araştırma modelindeki dişsal ve içsel değişkenler arasındaki ilişkileri doğrulamak ve belirlenen modeli araştırma evrenine genellemek için iki adımda gerçekleştirilen YEM analizi uygulandı:

(i) Bağımlı ve bağımsız değişkenler arasındaki ilişkinin gücünü gösteren yol (path) katsayıları belirlenerek, hipotezler test edildi.

(ii) Araştırma modelinin açıklayıcı gücü $\mathrm{R}^{2}$ değerleri ile gösterildi.

\subsection{YEM Analizi}

Teorik modelin YEM analizi yapıldığında, t-değerlerine göre, EGTT-EVV, DENN-EVV, YONN-EVV yolları anlamlıdır (Şekil 4).

Şekil 4. Teorik Modelin YEM Grafiği

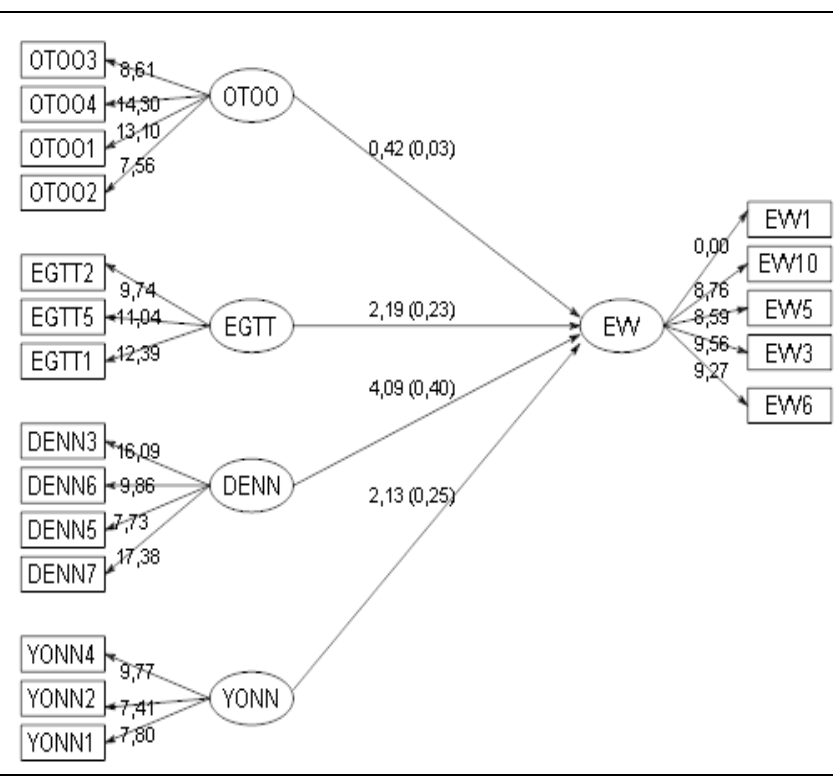

YEM analizinin uyum istatistiği değerleri istenen düzeydedir. Ki-Kare/SD 1,820, RMSEA 0,050, NFI 0,935, CFI 0,969, SRMR 0,0499, GFI 0,926 (Tablo 9).

Tablo 9. Teorik Modelin YEM Analizinin Uyum İstatistiği Değerleri

\begin{tabular}{cccc}
\hline $\begin{array}{c}\text { Uyumluluk } \\
\text { İndeksi }\end{array}$ & $\begin{array}{c}\text { Modifikasyon } \\
\text { Sonras1 } \\
\text { Değerler }\end{array}$ & İyi Uyum & $\begin{array}{c}\text { Kabul Edilebilir } \\
\text { Uyum }\end{array}$ \\
\hline $\begin{array}{c}\text { Ki- } \\
\text { Kare/SD }\end{array}$ & $\begin{array}{c}256,74 / 141= \\
1,820\end{array}$ & $1-2$ & $3-5$ \\
\hline RMSEA & 0,050 & $0<\mathrm{RMSEA}<0,05$ & $0,05<\mathrm{RMSEA}<0,10$ \\
\hline NFI & 0,935 & $0,95 \leq \mathrm{NFI} \leq 1,00$ & $0,90 \leq \mathrm{NFI} \leq 0,95$ \\
\hline CFI & 0,969 & $0,95 \leq \mathrm{CFI} \leq 1,00$ & $0,90 \leq \mathrm{CFI} \leq 0,95$ \\
\hline SRMR & 0,0499 & $0,00 \leq \mathrm{SRMR} \leq 0,05$ & $0,05 \leq \mathrm{SRMR} \leq 0,10$ \\
\hline GFI & 0,926 & $0,95 \leq \mathrm{GFI} \leq 1,00$ & $0,90 \leq \mathrm{GFI} \leq 0,95$ \\
\hline
\end{tabular}

Teorik modelin YEM analizi sonundaki bağlantı katsayılarına ve t-değerlerine göre, OTOO-EVV yolu ile ilgili hipotez çok zayıf bir ilişki olduğu için reddedilmiştir. 
EGTT-EVV, DENN-EVV, YONN-EVV yolları ilgili hipotezler kabul edilmiştir. OTOO-EVV standart katsayısı $(0,03)$ ve $\mathrm{t}$-değeri $(0,42<1,96)$ olduğundan, bu iki değişken arasında bir ilişki yoktur. Buna bağlı olarak "H1: Otomosyon enerji verimliliğini olumlu ve pozitif olarak etkilemektedir" hipotezi reddedildi.

Tablo 10. Teorik Modeldeki Hipotezlerin Test Sonuçları

\begin{tabular}{lccc}
\hline & Standart Değerler & t-değerleri & Sonuç \\
\hline OTOO-EVV (H1) & 0,03 & 0,42 & Ret \\
EGTT-EVV (H2) & 0,23 & 2,19 & Kabul \\
DENN-EVV (H3) & 0,40 & 4,09 & Kabul \\
YONN-EVV (H4) & 0,25 & 2,13 & Kabul \\
\hline
\end{tabular}

YEM Denklemi

$\mathrm{EVV}=$

$0,0364 *$ OTOO $+0,248 *$ EGTT $+0,431 * \mathrm{DENN}+0,266 * \mathrm{YONN}$

Errorvar. $=0,496, \mathrm{R}^{2}=0,580$

Teorik modelin YEM denkleme göre, EVV ile OTOO arasında pozitif yönde çok zayıf bir ilişki vardır $(0,0364)$ ve bu istatistiksel olarak anlamlı bir ilişki değildir. Bu değer EVV'deki “1” birimlik artışın OTOO'da 0,0364 oranında artışa veya bunun tam tersi EVV'deki azalışın OTOO'da azalışa neden olacağını göstermektedir.

EVV ile EGTT arasında pozitif yönde istatistiksel olarak anlamlı bir ilişki vardır. EVV'deki “1” birimlik artış EGTT'de 0,248 oranında artışa neden olmaktadır veya EVV'deki azalış, EGTT'de azalışa neden olmaktadır.

EVV ile DENN arasında pozitif yönde istatistiksel olarak anlamlı bir ilişki vardır. EVV'deki “1” birimlik artış DENN'de 0,431 oranında artışa neden olmaktadır veya EVV'deki azalış, DENN'de azalışa neden olmaktadır.

EVV ile YONN arasında pozitif yönde istatistiksel olarak anlamlı bir ilişki vardır. EVV'deki "1" birimlik artış, YONN'de 0,266 oranında artışa neden olmaktadır veya EVV'deki azalış, YONN'de azalışı neden olmaktadır. Sonuç olarak EVV, OTOO-YONN-DENN-EGTT faktörleri tarafından $\left(\mathrm{R}^{2}=0,580\right)$ oranında açıklanmaktadır. Temel bir kural olarak, her bir değişkenin yük değerinin 0,32 ve daha üzerinde değerlendirilmesi gerekir. Yük değerinin 0,71 olması halinde (varyansın \%50'sini açıklar) mükemmel, $\% 63$ olması halinde varyansın (varyansın \%40'nı açıklar) çok iyi, \%55 olması halinde (varyansın \%30'nu açıklar) iyi, $\% 45$ olması halinde (varyansın \%20'sini açıklar) vasat, \%30 olması halinde (varyansın \%10'nu açıklar) zayıf olarak değerlendirilmektedir (Büyüköztürk vd., 2010: 194). Bu duruma göre $\mathrm{R}^{2}=0,580$ olması iyi sonuç alındığını göstermektedir.

\section{Sonuç ve Öneriler}

Enerji verimliliği, denetim, otomasyon, eğitim, yönetim faktörlerinin ilişkileriyle oluşturulmuş olan teorik model, iki aşamada test edildi. Birinci aşamada gizil değişkenlerin gözlenen değişkenlerle desteklenip desteklenmediği ölçüm modeli ile test edildi. Elde edilen sonuçlara göre modelde düzenleme yapılarak oluşturulan modelde sorun olmadığ1 anlaşılması üzerine, bu değișkenler arasındaki neden-sonuç ilişkileri YEM ile test edildi.

Teorik modelin YEM analizi sonundaki bağlantı katsayılarına ve t-değerlerine göre, OTOO-EVV yolu ile ilgili hipotez reddedildi, EGTT-EVV, DENN_EVV, YONNEVV yolları ile ilgili hipotezler kabul edildi. Teorik modelin
YEM denklemine göre, EVV ile OTOO arasında pozitif yönde çok zayıf bir ilişki vardır ve bu ilişki istatistiksel olarak anlamlı bir ilişki değildir.

EVV ile EGTT arasında pozitif yönde istatistiksel olarak anlamı bir ilişki vardır, t- değerlerine göre Eğitim Faktörünün açıklama gücü en yüksek maddesi "EGTT1. Çalışanlara enerji verimliliğini sağlamak için nelere dikkat etmeleri gerektiği eğitim çalışmalarında açıklanmaktadır" maddesidir.

EVV ile DENN arasında pozitif yönde istatistiksel olarak anlamı bir ilişki vardır, t- değerlerine göre Eğitim Faktörünün açıklama gücü en yüksek maddesi "DENN7. Yönetim enerji verimliliğine önem veren bir anlayışa sahiptir" maddesidir.

EVV ile YONN arasında pozitif yönde istatistiksel olarak anlamı bir ilişki vardır, t- değerlerine göre Eğitim Faktörünün açıklama gücü en yüksek maddesi "YONN4. Yönetim benzer fabrikalardaki enerji tüketim miktarları ile kendi enerji tüketim miktarını karşılaştırmaktadır" maddesidir.

Araştırma analiz sonuçlarına göre sektördeki imalat işletmelerinde enerjinin verimli kullanılabilmesi için kendi olanakları kapsamında bazı önlemler alınması mümkündür ancak yeterli değildir. Bunun yanı sıra özellikle gelişmekte olan ülkelerin sanayi sektöründe, enerji tasarrufu potansiyelinin ekonomiye kazandırılması ise, enerji politikalarının kararlı bir şekilde uygulanması ile elde edilebilecektir. İmalat işletmelerinde enerjinin verimli kullanılmasıyla ilgili yönetimin desteğinin olması gerektiği, çalışanların bu konuda eğitime tabi tutulmaları ve belirli zaman dilimlerinde uygulamanın denetlenmesi konularında özenle çalışmalarda bulunulmalıdır. Enerji verimliliği bilinci her düzeyde geliştirilmeli, var olan enerji politikalarına ilave enerji tasarrufu politikaları oluşturulmalı ve denetim mekanizması ile kontrol sağlanmalıdır. Özellikle ülkemizde bu yönde yapılacak çalışmaların arttırılması son derece önemli ve sağlayacağı katkı maliyetler, rekabet ve karlılık konularında çok büyük olacaktır.

Bu çalışmada, enerji verimliliği üzerine etki eden dört faktör ele alınmıştır. Bu dört faktör enerji verimliliğine ait varyansın \% 58'ini açıklamaktadır. Varyansın açıklanamayan \%42'lik kısmını başka değişkenlerle açıklamak mümkündür. Yapılacak yeni çalışmalarda enerji verimliliğini etkileyen başka değişkenler ele alınabilir. Sektörel farklılıkların ortaya konulabilmesi için farklı sektörlerde anket uygulanıp sektörel karşılaştırma yapılabilir. İşletme büyüklüğüne göre enerji verimliliği açısından farklılıklar karşılaştırılabilir. Anket sadece mavi yakalılara uygulanmıştır. Yeni çalışmalarda hem mavi hem de beyaz yakalılara uygulanarak beyaz ve mavi yakalıların, konuya bakışları arasında fark olup olmadığı ortaya konulabilir.

\section{Kaynakça}

Acar E. (2012). Enerji Yoğunluklu Bir Fabrikanın Enerji Verimliliği Özelinde Incelenmesi. Yüksek Lisans Tezi. Ankara:Gazi Üniversitesi.

Adıgüzel, C. (2011). Enerjinin Verimli ve Etkin Kullanımına Yönelik Verimlilik Arttırıcı Proje Geliştirilmesi ve Bir Iş Merkezine Uygulanması. Yüksek Lisans Tezi. İstanbul: Yıldız Teknik Üniversitesi. 295842

Arıkan, A. (2010). Metal Eşya Sektöründe Faaliyet Gösteren Bir Firmada Enerji Tasarrufuna Yönelik Durum 
Çalışması. Yüksek Lisans Tez. Eskișehir: Osmangazi Üniversitesi. 255987

Artar, A. (1992). Imalat Sanayii Alt Sektörlerinde Verimlilik ve Firmalar arası Karşılaştırmalar. Milli Prodüktivite Merkezi Yayınları. 505.

Aydin, C., \& Esen, Ö. (2018). Does the level of energy intensity matter in the effect of energy consumption on the growth of transition economies? Evidence from dynamic panel threshold analysis. Energy Economics, 69, 185-195.

Bayraktar, G. (2004). Bir İlaç Üretimi Tesisinde Enerji Verimliliğinin Incelenmesi. Yüksek Lisans Tezi. Kocaeli: Gebze İleri Teknoloji Enstitüsü.

Büyüköztürk, Ş., Çokluk, B. Ö., \& Şekercioğlu, G. (2010), Sosyal Bilimler İçin Çok Değişkenli İstatistik SPSS ve LISREL Uygulamalarl. Ankara: Pegem Akademi.

Çelik, H., \&Yılmaz, V. (2013). Lisrel 9.1 ile Yapısal Eşitlik Modellemesi Temel Kavramlar Uygulamalar Programlama. An kara: Anı Yayıncilık.

Demirtaş, N. (2002). Sanayide Enerji Verimliliği ve Uygulaması. Yüksek Lisans Tezi. Eskişehir: Osmangazi Üniversitesi.

Erarslan, Y. (2011). Enerji Yönetim sisteminin Örnek Bir Işletmede Uygulanması. Yüksek Lisans Tezi, Niğde: Niğde Üniversitesi. 297598.

Eser, O. (2013). Aydinlatma Sistemlerinde Enerji Verimliliğinin Incelenmesi. Yüksek Lisans Tezi. İstanbul: Marmara Üniversitesi.

Gökmen, M. R. (2010). Endüstri Tesislerinde Enerji Verimli Aydınlatma Teknikleri ve Örnek Çalışma. Yüksek Lisans Tezi. İstanbul: İstanbul Teknik Üniversitesi.

Korkmaz, F. (2012). Türkiye Çay Sektörünün Mevcut Durumu ve Bir Çay Fabrikasında Enerji Verimliliği Analizi. Yüksek Lisans Tezi. İstanbul: İstanbul Teknik Üniversitesi.

Kreliner, B., Kunis, R., \& Rünger, G. (2011). Modeling of Energy-Sensitive Manufacturing Processes,9th IEEE International Conference on Industrial Informatics (INDIN), DOI: 10.1109/INDIN.2011.6034898.

Niesing, G., \& Grobler, L. J. (2013, August). Business basics for energy efficiency-Using the principles of energy management combined with renewable energy to achieve sustainable savings-A case study. In: 2013 Proceedings of the 10th Industrial and Commercial Use of Energy Conference (pp. 1-5). IEEE.

Otomasyon (2015). Enerji Otomasyonuna Genel Bakış. (Erişim Tarihi: 09.05.2015), www.otomasyondergisi.com.tr/arsiv/yazi/77-enerjiotomasyonuna-genel-bakis

Özel, C. (2010). Isşletmelerde Enerji Verimliliği Çalışmalarının Incelenmesi ve Hizmet Sektöründe Bir Araștırma. Yüksek Lisans Tezi. İstanbul: Marmara Üniversitesi.

Özkök, M. (2010). Enerji Yoğun Bir Tesiste Enerji Verimliliği Proje Tasarımı ve Uygulama Çalışması. Yüksek Lisans Tezi. Ankara: Gazi Üniversitesi.
Paulo, F., \& Gomes, A. (2009, June). Energy services as a tool to promote energy efficiency in the health sector. In 2009 IEEE Bucharest PowerTech (pp. 1-5). IEEE.

Polat, E. (2013). Türkiye'deki Kobilerde Düşük Maliyetli Enerji Verimliliği Yönetim Sistemi. Yüksek Lisans Tezi. İstanbul: Fatih Üniversitesi.

Sipahi, Ç. (2010). Sosyal Bilimlerde SPSS ile Veri Analizi. İstanbul: Beta Yayınevi.

Sürekli Gülcan., D. (1999). Lastik Endüstrisinde Enerji Yönetimi. Yüksek Lisan Tezi. İstanbul: Boğaziçi Üniversitesi.

Şimşek, Ö. F. (2007). Yapısal Eşitlik Modellenmesine Giriş Temel Ilkeler ve LISREL Uygulamalart. Ankara: Ekinoks Yayınları.

Taner, T. (2013). Gıda Sektöründe Enerji Verimliliği ve Enerji Yönetimi: Şeker Fabrikası Örneği. Doktora Tezi. Ankara: Gazi Üniversitesi. 330636.

Uylukçuoğlu, Ö. E. (2009). Otomotiv Sanayinde Enerji Verimliliği ve Enerji Tasarruf Olanaklarınin Belirlenmesi. Yüksek Lisans Tezi. İstanbul: İstanbul Teknik Üniversitesi.

Yörük, N. (2011). Bir Işs Merkezinde Enerjinin Etkin Kullanımının Incelenmesi. Yüksek Lisans Tezi. İstanbul: Yıldız Teknik Üniversitesi. 